\title{
New Discussion on the Credit Risk Influential Factors of Banking Loans among Small and Medium Enterprises
}

\section{— From Evidence of a Latest Survey of Small and Medium Enterprises}

\author{
Chunyu Li $\mathbf{i}^{1, \mathbf{a}}$ \\ ${ }^{1}$ School of Management and Economics, Beijing Institute of Technology, Beijing, 102448, China
}

Keywords:Small and medium enterprise loans, Credit risks, Bank-enterprise relations, Political relations

\begin{abstract}
By using an investigation data for the operation situation among small and medium enterprises in some area of Guangdong Province in 2015, this paper has analyzed multiple aspects of factors that may affect the credit risks of small and medium enterprises relatively comprehensively. On the basis of previous theoretical and empirical research, it is found in this paper that except for some important financial indexes, some predictable characteristics of small and medium enterprises and enterprise owners may also relate to risk factors. In addition, it is also found in this paper that the political identity or political relations of enterprise owners may have the negative relations with the credit risks of enterprises, demonstrating that non-efficiency distribution led by non-official relations may exist in the loan distribution process. This factor is not beneficial to establishing the benign bank-enterprise relations and solving the loaning problem of small and medium enterprises. Therefore, it needs the further specific research and corresponding policies as the countermeasures.
\end{abstract}

\section{Introduction}

In the current transition upgrading form of Chinese economy, the regional development and transitional upgrading of small and medium enterprises has played the very important role. On one hand, these small and medium enterprises are important forces to solve the employment. From the angle of banks, loans make small and medium enterprises burden higher risks and information costs obviously, which will cause the negative incentives on banks' loans to small and medium enterprises. From another angle, if banks and related supervision institutions have the more abundant understanding of the loaning credit risks of small and medium enterprises. On this basis, qualified small and medium enterprises have more possibility to obtain corresponding loaning chances, which is not only beneficial to the healthy economic increase, but also favorable to the profits of banks. It makes the research of small and medium enterprise credit risk rather important and urgent, which is also the main motive of research in this paper.

\section{Literature Review and Background Analysis}

Combing with the specific national situation background and economic conditions of China, some part of existing literature have discussed the credit risk problems of small and medium enterprises. Cao Fengqi (2001) put forward that the financing channel is very narrow in the operation development process of small and medium enterprises, which lacks the chances and mechanism of external market financing, so as to restrain the enterprise development. On the basis of further analyzing the experiences of foreign development, Cao Fengqi put forward to make the proper intervene for the government at the current stage. By issuing the corresponding policies and funds, it helps small and medium enterprises to establish the effective credit guarantee mechanism. Similarly, Xin Fei, Sun Guangyong and Deng Jing (2005) also analyzed the experiences of small and medium enterprises' development in the process of soaring economy in Japan, and the author used his credit experiences and systems of three large Japanese organizations to put forward the enlightenment of measurement risk degree. 


\section{Data description and metering model}

The data in this paper comes from the sampling investigation on the operation situation of local small and medium enterprises made in some administrative area of Guangzhou Province. Compared to the research mentioned in the above paper, the biggest advantage of the data used in this paper is the relatively large sample volume, and data upgrading can reflect the current economic trend. This investigation is made in all county-level units of this administrative area in summer vocation of 2015, and the main investigation objects are enterprises of each county, including factories, small companies, individual industrial households and other small and medium enterprises that behave actively in county-level economy. And the metering model adopted in this paper is as below:

(1) Linear possibility model

$$
\mathrm{y}=\mathrm{X} \beta+\varepsilon,
$$

Among which y is 0-1 variable that represents whether enterprises have the default behaviors, $\mathrm{y}=1$ represents that investigation results have the default behaviors. $\mathrm{X}$ includes a series of controlling variables of the characteristics of enterprises and enterprise owners, $\varepsilon$ is the random interruption term of regression.

(2)Probit model

$$
P(y=1)=F(X \beta),
$$

among which $\mathrm{F}($.$) is the accumulative density function with the standard Gaussian distribution.$ (3)Logit model

among which $\mathrm{F}(\mathrm{u})=\frac{\mathrm{e}^{\mathrm{u}}}{1+\mathrm{e}^{\mathrm{u}}}$.

$$
P(y=1)=F(X \beta)
$$

\begin{tabular}{|c|c|c|c|c|}
\hline $\begin{array}{l}\text { Independent } \\
\text { variable }\end{array}$ & $\begin{array}{c}\text { Variable } \\
\text { interpretation }\end{array}$ & $\begin{array}{c}\text { (1) } \\
\text { Default } \\
\text { probability }\end{array}$ & $\begin{array}{c}\text { (2) } \\
\text { Default } \\
\text { probability }\end{array}$ & $\begin{array}{c}\text { (3) } \\
\text { Default } \\
\text { probability }\end{array}$ \\
\hline Revenue & Total revenue in 2014 & $\begin{array}{l}-9.20 \mathrm{e}-07 \\
(9.46 \mathrm{e}-07)\end{array}$ & $\begin{array}{c}-3.25 \mathrm{e}-05^{* * *} \\
(1.12 \mathrm{e}-05)\end{array}$ & $\begin{array}{c}-3.85 \mathrm{e}-05^{* * *} \\
(1.49 \mathrm{e}-05)\end{array}$ \\
\hline Profit & Net profit in 2014 & $\begin{array}{l}3.80 \mathrm{e}-05^{*} \\
(1.95 \mathrm{e}-05)\end{array}$ & $\begin{array}{c}5.34 \mathrm{e}-05 \\
(6.06 \mathrm{e}-05)\end{array}$ & $\begin{array}{c}6.00 \mathrm{e}-05 \\
(7.19 \mathrm{e}-05)\end{array}$ \\
\hline Ratio receivables & Receivables/ revenue & $\begin{array}{l}0.128 * * \\
(0.0540)\end{array}$ & $\begin{array}{l}0.131 * * \\
(0.0658)\end{array}$ & $\begin{array}{c}0.134 * \\
(0.0685)\end{array}$ \\
\hline Fixed assets & Scale of fixed assets & $\begin{array}{c}-2.29 \mathrm{e}-05^{* * *} \\
(5.24 \mathrm{e}-06)\end{array}$ & $\begin{array}{c}-0.000113 * * * \\
(2.61 \mathrm{e}-05)\end{array}$ & $\begin{array}{c}-0.000148 * * * \\
(3.51 \mathrm{e}-05)\end{array}$ \\
\hline Asset turnover & Revenue/ fixed assets & $\begin{array}{l}3.31 \mathrm{e}-05 \\
(6.18 \mathrm{e}-05)\end{array}$ & $\begin{array}{l}8.18 \mathrm{e}-05 \\
(7.25 \mathrm{e}-05)\end{array}$ & $\begin{array}{l}9.05 \mathrm{e}-05 \\
(7.40 \mathrm{e}-05)\end{array}$ \\
\hline Worker number & Number of permanent staff & $\begin{array}{c}-0.000741^{* * *} \\
(0.000162)\end{array}$ & $\begin{array}{l}-0.00184 * * * \\
(0.000661)\end{array}$ & $\begin{array}{l}-0.00183 * * \\
(0.000803)\end{array}$ \\
\hline Temp number & Number of temporary staff & $\begin{array}{l}-0.000316 \\
(0.000514)\end{array}$ & $\begin{array}{c}0.00525 \\
(0.00369)\end{array}$ & $\begin{array}{c}0.00426 \\
(0.00376)\end{array}$ \\
\hline High school & $\begin{array}{l}\text { High school ratio in permanent } \\
\text { staff }\end{array}$ & $\begin{array}{c}-0.00188 * * * \\
(0.000318)\end{array}$ & $\begin{array}{l}-0.00177 * * * \\
(0.000389)\end{array}$ & $\begin{array}{c}-0.00182 * * * \\
(0.000406)\end{array}$ \\
\hline Temp high school & High school ratio in temporary & $-0.00162 * * *$ & $-0.00182 * *$ & $-0.00185^{* *}$ \\
\hline
\end{tabular}

\section{Estimation Results and Discussion}

Table 1. Analysis on influential factors of loan defaults of small and medium enterprises 


\begin{tabular}{|c|c|c|c|c|}
\hline & staff & $(0.000603)$ & $(0.000767)$ & $(0.000790)$ \\
\hline \multirow[t]{2}{*}{ Male } & Entrepreneur's gender (male) & $0.0515^{* *}$ & 0.0268 & 0.0275 \\
\hline & & $(0.0211)$ & $(0.0270)$ & $(0.0295)$ \\
\hline \multirow[t]{2}{*}{ Age } & Entrepreneur's age & $0.00350^{* * *}$ & 0.00232 & 0.00206 \\
\hline & & $(0.00122)$ & $(0.00160)$ & $(0.00172)$ \\
\hline \multirow[t]{2}{*}{ Party } & Entrepreneur is a party member & $0.161^{* * *}$ & $0.138 * * *$ & $0.140 * * *$ \\
\hline & & $(0.0358)$ & $(0.0493)$ & $(0.0498)$ \\
\hline \multirow[t]{2}{*}{ Congress } & Entrepreneur is a deputy & $0.0563 * *$ & 0.130 & $0.139 * *$ \\
\hline & & $(0.0218)$ & $(0.101)$ & $(0.063)$ \\
\hline \multirow{2}{*}{ Consultative } & $\begin{array}{l}\text { Entrepreneur is a National } \\
\text { Committee member }\end{array}$ & $0.193 * * *$ & $0.207 * *$ & 0.167 \\
\hline & & $(0.0576)$ & $(0.104)$ & $(0.111)$ \\
\hline \multirow[t]{2}{*}{ Edu primary } & Primary school education & 0.0860 & $0.185^{*}$ & $0.208^{*}$ \\
\hline & & $(0.0678)$ & $(0.106)$ & $(0.122)$ \\
\hline \multirow[t]{2}{*}{ Edu juniorhigh } & Junior school education & 0.102 & $0.191^{* *}$ & $0.220^{*}$ \\
\hline & & $(0.0629)$ & $(0.0968)$ & $(0.117)$ \\
\hline \multirow[t]{2}{*}{ Edu seniorhigh } & Senior school education & $-0.146^{* *}$ & $-0.230 * *$ & $-0.257 * *$ \\
\hline & & $(0.0642)$ & $(0.0993)$ & $(0.118)$ \\
\hline \multirow[t]{2}{*}{ Education College } & A bachelor degree & $-0.168 * *$ & -0.167 & -0.179 \\
\hline & & $(0.0686)$ & $(0.108)$ & $(0.123)$ \\
\hline \multirow[t]{2}{*}{ Education Master } & A master degree and above & $-0.269 * *$ & -0.0401 & -0.0849 \\
\hline & & $(0.123)$ & $(0.218)$ & $(0.251)$ \\
\hline \multirow[t]{2}{*}{ Experience SOE } & $\begin{array}{l}\text { Have the experience of } \\
\text { State-owned enterprise }\end{array}$ & 0.0245 & 0.0525 & 0.0561 \\
\hline & & $(0.0366)$ & $(0.0485)$ & $(0.0502)$ \\
\hline \multirow[t]{2}{*}{ Experience Public } & $\begin{array}{l}\text { Have the experience of public } \\
\text { services }\end{array}$ & -0.0602 & -0.0460 & -0.0445 \\
\hline & & $(0.0464)$ & $(0.0591)$ & $(0.0674)$ \\
\hline \multirow[t]{2}{*}{$\begin{array}{l}\text { Experience } \\
\text { government }\end{array}$} & $\begin{array}{l}\text { Have the experience of } \\
\text { public services }\end{array}$ & -0.0562 & -0.0886 & -0.0757 \\
\hline & & $(0.0638)$ & $(0.0793)$ & $(0.0976)$ \\
\hline \multirow[t]{2}{*}{ Tax policy } & Have the tax preference & -0.00142 & 0.0304 & 0.0330 \\
\hline & & $(0.0209)$ & $(0.0271)$ & $(0.0297)$ \\
\hline \multirow[t]{2}{*}{ License policy } & $\begin{array}{l}\text { Difficulty level of applying for } \\
\text { licenses }\end{array}$ & 0.00557 & 0.00437 & 0.00348 \\
\hline & & $(0.0122)$ & $(0.0158)$ & $(0.0172)$ \\
\hline \multirow[t]{2}{*}{ Land policy } & Difficulty level of obtaining land & 0.00311 & -0.00506 & -0.00549 \\
\hline & & $(0.00970)$ & $(0.0124)$ & $(0.0135)$ \\
\hline \multirow[t]{2}{*}{ Constant } & & -0.114 & & $-0.706^{* * *}$ \\
\hline & & $(0.102)$ & & $(0.161)$ \\
\hline \multicolumn{2}{|l|}{$\begin{array}{l}\text { Fixed effect of } \\
\text { control industry }\end{array}$} & $\checkmark$ & $\checkmark$ & $\checkmark$ \\
\hline \multirow{2}{*}{\multicolumn{2}{|c|}{$\begin{array}{l}\text { Observations } \\
\text { R-squared }\end{array}$}} & 1,910 & 1,910 & 1,910 \\
\hline & & 0.194 & & \\
\hline
\end{tabular}

Standard errors in parentheses

*** $\mathrm{p}<0.01$, ** $\mathrm{p}<0.05,{ }^{*} \mathrm{p}<0.1$ 
Compared with previous studies, larger samples and more detailed data allow this paper put in the same regression included many variables in various aspects, which can effectively deal with the estimation of omitted variable bias due. Accordingly, the regression analysis of this paper also contains a wealth of information, which can help us find some new conclusions.

First of all, the financial position of small and medium enterprises is indeed related to the risk of default. For example, firms with higher revenues and higher fixed asset value are less likely to default (but the impact of income is relatively small and not significant in the linear model). Accordingly, we find that the previous year's net profit may not have an impact, perhaps because short-term profits do not have a greater impact. The ratio of accounts receivable has a greater impact, and its estimate is robust. This conclusion is in line with economic intuition, accounts receivable accounted for higher revenue ratio, enterprises are more likely to suffer bad debts, liquidity problems, it is more prone to credit default. This part of the financial information can provide guidance on assessing the credit risk of small and medium enterprises, but the actual operation of the problem is difficult to obtain and observation (Jing Wong, 2011). It is one of the fundamental reasons for the loan difficulty of the small and medium enterprise. Therefore, we should focus on other indicators.

The second part is the scale of enterprises and other characteristics. Compared with the financial information, this part of the enterprise characteristics and business owners' personal characteristics are usually more easily observed. It can also provide more convenient and intuitive reference information. When employees measure the size of an enterprise, they also find that the bigger the size, the lower the default risk, but the number of casual workers has no effect. In addition, the average staff capital of employees is measured by the proportion of senior middle school students and above, and it is found that this index also has a negative impact on the risk of default.

The third part includes the personal characteristics of the business owner, including gender, age, education and so on. By comprehensively analyzing the regression results of the three models, we can conclude that the higher the age, the slightly higher the risk of breach of contract, while the higher educational background will reduce the risk of default. In this section, more importantly, this paper focuses on the impact of political identity and relationships. We found that if the business owner is a party member or a member of the National Committee and a deputy to the people's Congress. The default risk of small and medium enterprises will rise. According to the theories analysis of the first and second parts, the author assumed that the reason may lie in the process of obtaining loans. The business owners who have certain political resources are more likely to get loans. But it does not directly reflect the operational efficiency of enterprises. It shows that the political relations in the allocation of loan resources reduces the efficiency to some degree.

In addition, this paper also analyzes whether the work experience of state-owned enterprises, or government departments will have similar effects. But no significant results have been found. This may indicate that current relationships, rather than past relationships, are more likely to function.

In the fourth part, the regression also includes some variables associated with the local policy advantages, such as whether the enterprises enjoy preferential tax, and whether the enterprises can apply for licenses and obtain the land easily in the start-up stage and the operation stage. These factors may also affect the operation of enterprises. But there are no direct relationships between them and credit risk according to the data in the paper.

\section{Conclusion}

In summary of the above analysis and empirical results, it is found in this paper that the financial situation of enterprises will affect the default risk indeed. However, this part of information is quite difficult to predict, which may need to combine with the guarantee mechanism and the bank-enterprise relations with the long-term cooperation. In addition, some external predictable characteristics between enterprises and their owners may have certain relations with the default risk of small and medium enterprises, and these factors may have certain reference values for the overall default risk of small and medium enterprises estimated by banks. More importantly, it is found in this paper that the political relations of enterprise owners may have the negative effects on default behaviors instead. The future research can further analyze the specific reasons and mechanism that 
these non-marketing factors develop their function, as well as whether some adjustable information communication and supervision mechanism exist, so as to provide the better guidance for the practice of credits and loans among small and medium enterprises.

\section{References}

[1] He Ren,Wang Weicheng. Bank -firm Relationship and the Growth of SMEs:Evidence from the Value of Relationship Lending [J].Journal of Finance and Eco nomics, 2009, 35(10): 81-91.

[2] Wu Fan, Yang Yang. Experience and Enlightenment of Constructing Credit Guarantee Systemof Small and Medium-sized Enterprises in Japan [J].Business Economy, 2010(1): 68-70.

[3] Li Xiyi, Miao Haibo. The Key Problem for Restricting Bank Loans to Support Technology-based Small and Medium-sized Enterprises- A Survey Study of Beijing [J].Forum on Science and Technology in China, 2015(8): 116-120.

[4] Zhu Yujie, Song Bin. Empirical Analysis on Influenc in gFactors of Loan Cost of Chinese Small and Medium Sized Enterprises [J].Technology Economics, 2016, 35(10): 86-93.

[5] Berglof, E., \& Roland, G. Soft budget constraints and banking in transition economies [J]. Journal of Comparative Economics, 1998, 26(1): 18-40.

[6] Tian, L., \& Estrin, S. Debt financing, soft budget constraints, and government ownership Evidence from China [J]. Economics of Transition, 2007, 15(3): 461-481. 